\title{
Preparation of Panification Products Using Passion Fruit in Replacement of Wheat Flour
}

\author{
Fernanda Antonia de Souza Oliveira ${ }^{1 *}$; Aurora Britto Andrade; Weena Rebeca Pinheiro Damasceno; \\ Rebeca dos Reis Magalhães Azevêdo²; Renato Souza $\mathrm{Cruz}^{2}$ \\ ${ }^{1}$ Federal University of Bahia, Department of Food Science; Salvador, Bahia; ${ }^{2}$ State University of Feira de Santana, Department \\ of Biothecnology; Feira de Santana, Bahia; Brazil
}

\begin{abstract}
Passion fruit (fruit of significant domestic production) has $52 \%$ of its weight comprised of peel (albedo), is rich in pectin, and has essential technological properties for bakery products. In the present coursework, the production of passion fruit albedo flour (FAM) was carried out, later used in different concentrations to produce pasta $(4 \%, 8 \%, 12 \%$, and $16 \%)$ and cookies $(3 \%, 6 \%, 9 \%$, and $12 \%)$. Physical and technological analyses were performed to characterize the products. The data treatment showed that the ideal concentration of FAM for pasta is $\mathbf{1 5 \%}$, and for the cookie, the maximum incorporation did not present a significant difference. We concluded that FAM has excellent potential for use in baking, being necessary further adjustments.
\end{abstract}

Keywords: Pasta. Cookie. Passion Fruit Albedo Flour.

Passion fruit (Passiflora edulis) is a fruit that has been gaining headway in the Brazilian agricultural market in the last four decades. The fruit cultivation has been explored and is already seen as an alternative for coffee producers because the faster financial return [1]. Today, Brazil is the largest producer of passion fruit in the world, yielding one million tons/year [2].

The genus Passiflora is represented by 530 species, being 140 natives of Brazil. Of these, only one is used for commercial purposes in the food production of nectars, juices, pulps, edible ice cream, jellies, and candies [3].

The productive chain uses the fruit pulp to manufacture the products, generating as residue: the bark, which represents $\sim 52 \%$ of the passion fruit weight; and the seeds, which represent 6\%-12\% [4,5]. The residue created from the passion fruit processing is vast and presents a high potential uses for enrichment other food products because

Received on 28 August 2019; revised 28 September 2019. Address for correspondence: Dr. Fernanda Antonia de Souza Oliveira. Universidade Federal da Bahia-UFBA; Faculdade de Farmácia, Rua Barão de Jeremoabo, 147, Ondina. Zip Code: 40170-210. Salvador, Bahia, Brazil. E-mail: fernandaasouzaoliveira2@gmail.com. This study was selected from the $\mathrm{V}$ International Symposium of Innovation and Technology - SIINTEC (October 2019).

J Bioeng. Biotech. Appl. Health 2019;2(3):99-104.

(C) 2019 by SENAI CIMATEC. All rights reserved. it is rich in pectin (a soluble fiber that aids in lowering blood glucose levels; besides presenting gelling properties of great interest to the industrys' foods), protein, B3 vitamin, and minerals [6].

Another use for the passion fruit shell is in the form of flour, which can be used in the bakery industry as an alternative to substitute the wheat flour [3]. According to ABIT (Associação Brasileira da Indústria de Panificação e Confeitaria) [7], the bakery segment creates around 800 thousand direct jobs and 1,8 million indirect in the approximately 70 thousand bakeries and patisseries in Brazil. Emphasizing the use of solid waste from agribusiness contributes to environmental conservation. Besides, it increases the nutritional value of food products [3], minimizing the occurrence of malnutrition due to lack of food, which is one of the aims of the program ONU 2030 - No Hunger and Sustainable Agriculture in Brazil.

The present study aimed to evaluate the technological and physical characteristics of passion fruit albedo flour, species genetically improved by Embrapa, as well as the biscuit and pasta produced from the increment of flour produced.

\section{Methods}

Flour Preparation

Passion fruit albedo (purple and yellow) was 
cut into slices and intended for drying in a tray dryer with forced air circulation at a temperature of $80^{\circ} \mathrm{C}$ for $8.5 \mathrm{~h}$. In order to determine the drying curves of the flour, moisture measurements were taken every 2 hours, until the albedo humidity was between $10 \%$ and $13 \%$, below the maximum limit of $15 \%$ [8]. They were then ground in a knife mill (TECNAL, TE-651) and sieved with a 30 mesh opening vibrating sieve, packed in $50 \mu \mathrm{m}$ thick of high-density polyethylene plastic containers, and stored at room temperature, $25 \pm 2{ }^{\circ} \mathrm{C}$ for storage, following analyzes. Flours were characterized by grain size [9] humidity, by the use of infrared scales and water absorption (ABS), with results expressed as a percentage (\%) of absorption.

\section{$\underline{\text { Product Development }}$}

\section{Pasta}

Indian extruder model Pasta Mini 5" (Água Rasa - São Paulo) processed the fresh pasta, containing 1: 1 compression ratio thread and noodles with 23 rectangular $1 \mathrm{~mm}$ x $5 \mathrm{~mm}$ holes, internally coated with Teflon. The dough was kneaded, mixed and extruded, and then dried in a forced-air dryer for further analysis. The parameters evaluated were: cooking time method 66-50 [10], weight gain, volume gain, and loss of soluble solids. The texture of the cooked pasta was determined using the TAXT plus Texturometer equipment with A / LKB-F, HDP / PFS and A / SPR accessories, to evaluate the firmness and shear force parameters [10].

Four noodle formulations were incorporated with passion fruit albedo flour (FAM) of the purple variety, with concentrations of $4 ; 8 ; 12$ and $16 \%$, in addition to the standard formulation (without additional passion fruit albedo flour) for comparison. The formulation consists of $3 \%$ oil, $1.5 \%$ salt, and water.

\section{Cookie}

The cookies were made with the incorporation of the yellow variety FAM in the proportions of F1 $3 \%$, F2 $6 \%$, F3 9\%, and F4 12\%, in addition to the standard formulation (F0), in which FAM is exempt for comparison purposes. All the ingredients, i.e., wheat flour, passion fruit albedo flour, sugar, butter, salt, and eggs, were mixed in a planetary mixer (Arno), its dough rolled and cut into $2 \mathrm{~cm}$ wide, $0.8 \mathrm{~cm}$ thick rectangles and $9 \mathrm{~cm}$ long, for baking and other analyzes. The analyzes were made of texture profile of the raw mass (hardness, adhesiveness, flexibility, and cohesiveness) and the texture of the cookie (hardness and fracturability) in texturometerTA.XT.plus. Also, weight, diameter, thickness, expansion factor, and specific volume were evaluated. AACC, Method 10-50 D [10].

\section{$\underline{\text { Statistical Analysis }}$}

The experiments were conducted in a completely randomized method, designed with three replications and evaluated by Tukey's range test, with a 5\% probability, using SAS software, version 9.0 .

\section{Results and Discussion}

Particle Size of Passion Fruit Flour of the Purple and Yellow Varieties

The results obtained in the particle size characterization of passion fruit albedo flours of purple and yellow varieties were respectively $44.40 \%$ in 42 mesh $(0.355 \mathrm{~mm})$ and $47.05 \%$ in the same aperture, indicating that both Flours, despite the different varieties, have similar grain size.

The particle size of the food after grinding is an essential aspect in the preparation of flour derivative, since a more excellent uniformity of the granulometry allows the preparation of a final product with better sensorial quality, mainly texture, taste and visual aspect. The food absorbs water evenly, resulting in uniform cooking of the product. Therefore, the grain size of the FAM of the two varieties does not present satisfactory uniformity for the preparation of bakery products [11].

Moisture of Passion Fruit Albedo Flour (Purple and Yellow) Varieties

Passion fruit albedo flour had a moisture content of $10.78 \pm 0.3 \%$ for the purple variety and $11.56 \pm$ 
$0.3 \%$ for the yellow variety. Moisture is a crucial aspect for the preservation of food quality, as it can directly influence the chemical composition, microorganism development, chemical, and enzymatic reactions, causing, among other damages, the decrease in the shelf life of the product [12].

\section{Flour Water Absorption Capacity}

Absorption analysis was performed on the two varieties of passion fruit albedo flour present in triplicates. It was also made with wheat flour incorporated with passion fruit albedo in the proportions $5 \%, 10 \%, 15 \%, 20 \%$, and $25 \%$. The results obtained for yellow, purple, and wheat flour AMF were respectively $559.83 \pm 1.36,549.84 \pm$ 0.17 , and $58.39 \pm 0.20$.

Both varieties are similar when we compared the results between the absorption values found in passion fruit albedo flour. Also, passion fruit flour has a much higher absorption compared to wheat flour. This superior FAM absorption value can be explained by the high fiber content present in passion fruit peel, especially pectin, when compared to the fiber content present in cereal bran and pulses. Furthermore, this high content of soluble fiber increases the nutritional value of foods, providing a reduction in glycemic response, helping in problems such as diabetes, cardiovascular problems, and obesity [13].

\section{Optimum Cooking Time}

Increasing FAM incorporation in the dough formulation led to a decrease in cooking time with a mean of $7.00 \pm 0.01 \mathrm{~min}$. Cooking time depends on dough cohesion through the interaction of gliadin and glutenin proteins and starch present [14].

\section{Absorption of the Water}

Absorption occurs in a significant model described as $0.011[\mathrm{FAM}]+2.03$ with $\mathrm{R}^{2}=0.83$, and its increase was already an expected factor due to the high fiber content found in FAM. Flours with a higher fiber and protein content retain a higher absorption [15]. Optimum cooking time was reduced, and absorption increased, leading to faster moistening and swelling of the starch, increasing gelatinization in a shorter time.

\section{Loss of Solids}

The loss of solids occurs by a significant model with $-0.03[\mathrm{FAM}]^{2}+, 72[\mathrm{FAM}]+6.24$ with $\mathrm{R}^{2}=$ 0.99 , the results show that from the incorporation of $5 \%$ of FAM, poor quality flour is already obtained, and the addition only increases the loss of solids and the maximum loss with the incorporation of $11.91 \%$ of FAM. Flours with greater grain size and fibrous parts, increase the loss of solids [11].

\section{Increase of the Volume}

For this parameter, we obtained a significant model described as 0.01 [FAM] +2.42 with $\mathrm{R}^{2}=$ 0.86 , an increase in the incorporation of FAM in the mass formulation generated a similar volume increase. The parameters weight gain and volume increase are related to the water absorption capacity of the pasta during cooking and depend on the shape of the pasta. The volume increase is classified as good with values in the range of 200 to $300 \%$ [16], which did not occur, the values below were found, and only the incorporation of $12 \%$ was satisfactory.

\section{Texture Analysis of Pasta Samples}

\section{Firmness}

The results show a significant model described as $0.401[\text { FAM }]^{2}-12.36[\mathrm{FAM}]+332.6$ with $\mathrm{R}^{2}=$ 0.85 (Figura 1).

The incorporation of the FAM generated a decrease in the firmness parameter, with its minimum point of $15.41 \%$ of the addition of passion fruit albedo flour. The use of nontraditional products interferes with the formation of the gluten matrix, weakening its bonds, making the system more fragile, and facilitating water penetration [17].

\section{Shear Strength}

The shear strength parameter has a significant 
mathematical model, described as 0.041 [FAM] ${ }^{2}-1.161[\mathrm{FAM}]+23.587$ with $\mathrm{R}^{2}=0.94$; as well as firmness, this parameter has its value reduced with the increase of the addition of passion fruit flour to the pasta, being its minimum value with the incorporation of $14.23 \%$ of FAM in its formulation (Figura 2).

Texture Analysis of Cookie Samples

Expansion and Thickness Index, Weight Loss, and Specific Mass

The results obtained from the expansion and thickness indices, weight loss and specific mass did not present a significant model, having as mean and standard deviation results $0.96 \pm 0.01 ; 0.94 \pm$ $0.38 ; 0.18 \pm 0.01$ and $0.97 \pm 0.15$ respectively.

\section{Cookie Texture: Hardness and Fracturability}

The hardness test results do not show a significant model, with average and deviation of $5791.26 \pm 692.48$. We observed the increase in fiber content in the product with the increase in the value of parameters related to food texture, such as hardness [18].

The fracturability, which forces the cookie to fracture, has a significant model with Fra $=$ $0.0042\left[^{[F A M}\right]^{2}+0.072[$ FAM $]+0.69$ with $\mathrm{R}^{2}$
$=0.92$. As hardness, it grows with the increased incorporation of passion fruit flour into the cookie dough formulation. It was expected, as a harder cookie is more difficult to break, the tensions of the forces required for the fracture become larger, having its peak with the addition of $8.57 \%$ of FAM (Figure 3).

\section{Conclusion}

We observed that the yellow and purple FAM did not present significant differences in the analyzed parameters. For the noodles, the best results were in the addition of $15 \%$ of FAM, where the shear strength and hardness were minimal, and the water absorption was close to the expected. Regarding the cookie, the addition of FAM did not present significant results. FAM presented technological problems, but improvements such as the uniformity of granules would be beneficial, significantly improving the quality of baked goods.

\section{Acknowledgment}

We thank the Fapesb funding agency (grant number 0650/2016).

Figure 1. Firmness parameter in pasta, in different percentages of passion fruit flour.

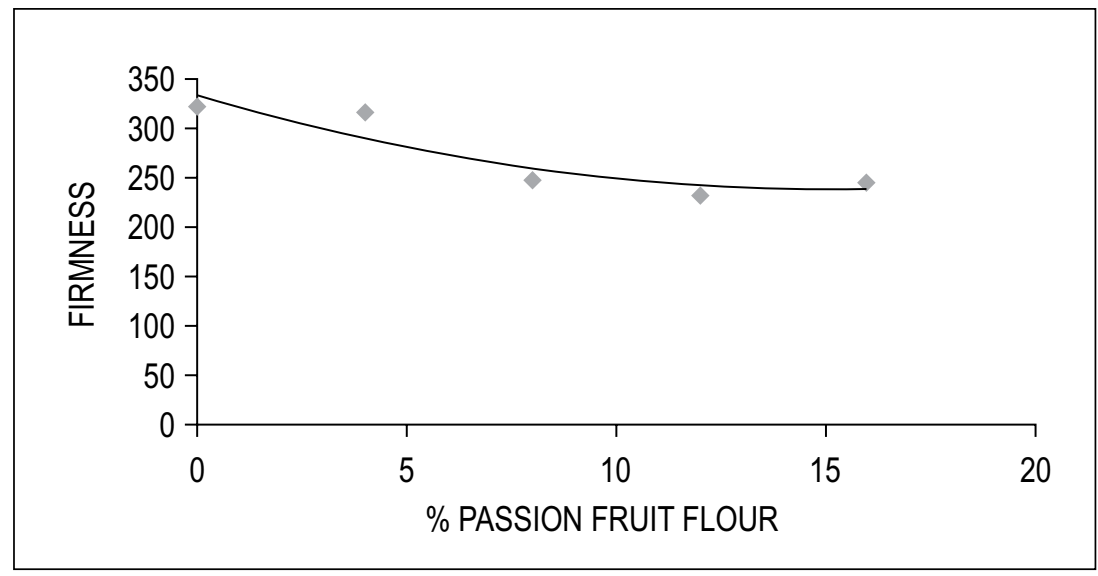


Figure 2. Shear strength parameter in pasta, with different percentages of passion fruit flour.

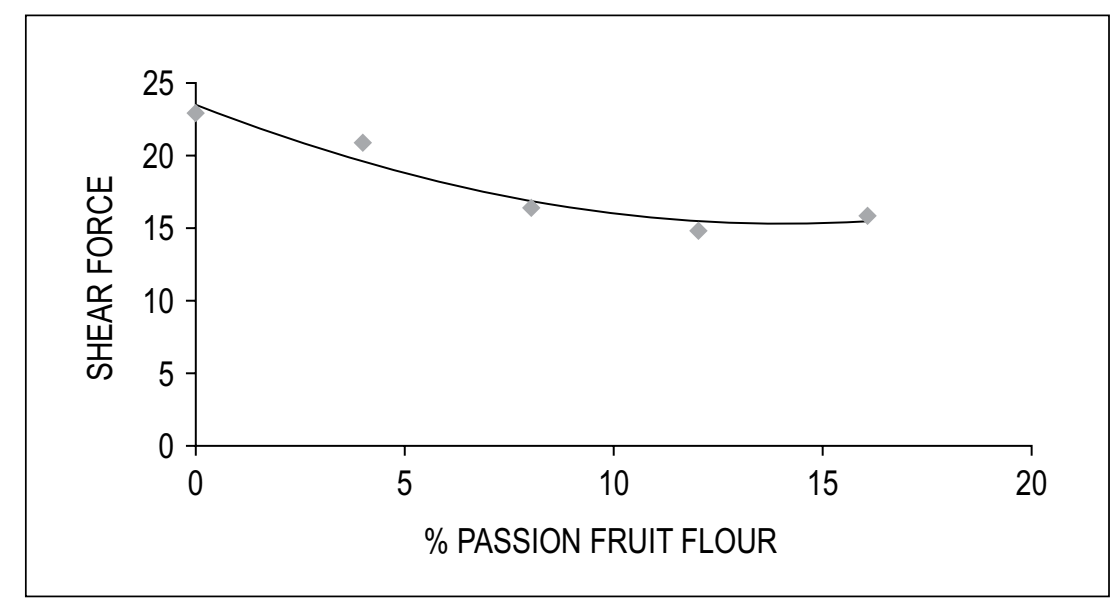

Figure 3. Parameter Fracturability in the cookie, in different percentages of passion fruit flour.

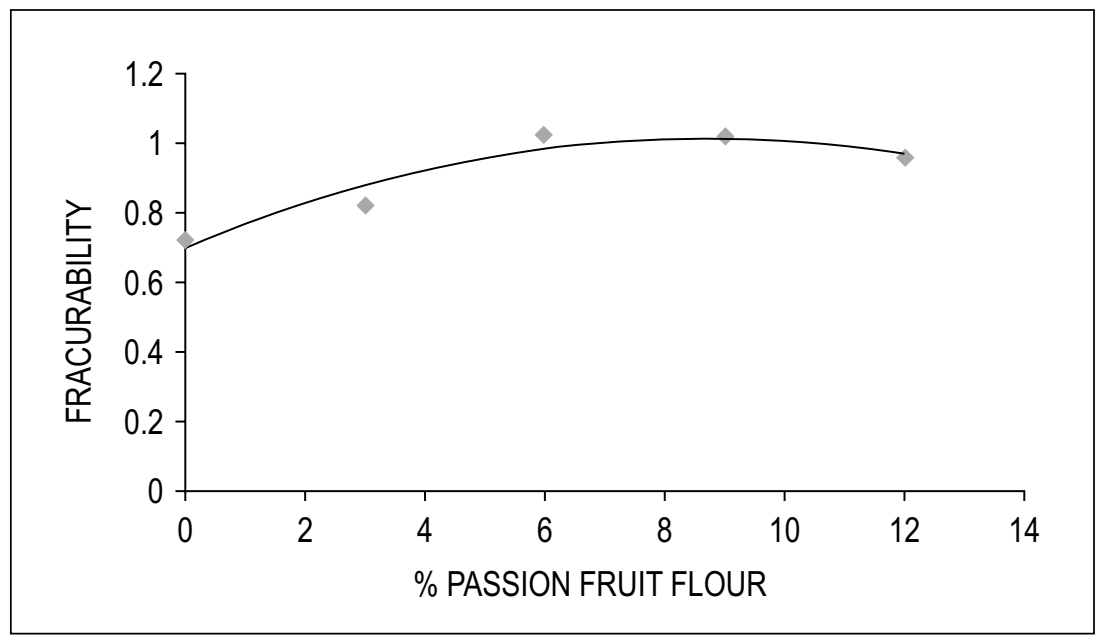

\section{References}

1. Meletti, L.M.M. Avanços na cultura do maracujá no Brasil. Revista Brasileira de Fruticultura. Jaboticabal. 2011;33.

2. Associação Brasileira de Produtores Exportadores de Frutas e Derivados-ABRAFRUTAS. Brasil é atualmente maior produtor mundial de maracujá, 2019. Disponível em: https://abrafrutas.org/2019/03/26/brasil. Acesso em: 20 de setembro de 2019.

3. Empresa Brasileira de Pesquisa AgropecuáriaEMBRAPA. Maracujá: o produtor pergunta, a Embrapa responde. Brasília, DF: Embrapa. 2016;3:341.
4. Ferrari, R.A., Colussi, F., Ayub, R.A. Caracterização de subprodutos da industrialização do maracujáaproveitamento das sementes. Revista Brasileira de Fruticultura. 2004;26(1).

5. Oliveira, E.M.S., Resende, E.D. Yield of albedo flour and pectin content in the rind of yellow passion fruit, Ciência e Tecnologia de Alimentos. 2012;32(3).

6. Matsuura, F.C.A.U. Estudo do albedo do maracujá e de seu aproveitamento em barras de cereais. 2005. 157 f. Dissertação (Mestrado em Engenharia de Alimentos) -Faculdade de Engenharia de Alimentos, Universidade Estadual de Campinas, Campinas, 2005. 
7. Associação Brasileira da Indústria de Panificação e Confeitaria - ABIT; Instituto Tecnológico - ITPC. Indicadores da panificação e confeitaria 2018. Available in: < http://www.agenciazaga.com/INDICADORES-DAPANIFICA $\%$ C $3 \% 87 \%$ C3\%83O-E-CONFEITARIA $\% 20$ BRASILEIRA\%202018.pdf> Accessed in: July 2019.

8. Brasil. Agencia Nacional de Vigilância SanitáriaANVISA. Resolução RDC n ${ }^{\circ} 263$, de 22 de setembro de 2005, Regulamento Técnico para produtos de cereais, amidos, farinhas e farelos, 2005.

9. Fernandes, A.F., Pereira, J., Germani, R., Oiano- Neto, J. Effect of the partial replacement of wheat flour for potato skin flour (Solanum Tuberosum L.), Ciência e Tecnologia de Alimentos, Campinas. 2008;28:56-65.

10. American Association of Cereal Chemists-AACC. 2000.

11. Franco, V.A. Desenvolvimento de pão se glúten de farinha de arroz e batata doce. 2015. 129 f. Dissertação (Mestrado em Ciência e Tecnologia de Alimentos) -Escola de Agronomia, Universidade Federal de Goiás, Goiânia. 2015.

12. Silva, R.F.,Ascheri, J.L.R.,Pereira, R.G.F.A.Composição centesimal e perfilde aminoácidos de arroz e pó de café. Alimentos e Nutrição, Araraquara. 2007;18(3):325-330.
13. Souza, M.W.S. de, Ferreira, T.B.O., Vieira, I.F.R. Composição centesimal epropriedades funcionais tecnológicas da farinha da casca do maracujá. Alimentos e Nutrição. Araraquara-SP. 2008;19(1):33-36.

14. Minguita et al. Produção e caracterização de massas alimentícias a base de alimentos bio fortificados: trigo, arroz polido e feijão carioca com casca. Ciência Rural, Santa Maria. 2015;45(10):1895-1901.

15. Martins, J.N., Oliveira, E.N.A. de, Santos, D.C. Estudo da absorção de água em misturas de farinhas de trigo em diferentes marcas comerciais. Revista Verde. MossoróRN. 2012;7(4):201-206.

16. Hummel, C. Macaroni products. London: Food Trade Press, p. 287, 1966.

17. Costa, T.V.M., Moura, C.M.A., Soares Jr,M.S. Qualidade tecnológica de massa alimentícia produzida a partir de farinhas de arroz e linhaça. Escola de Agronomia e Engenharia de Alimentos-Universidade Federal de Goiás, 2013.

18. Haddad, F.F. Barras alimentícias de sabor salgado com diferentes agentes ligantes: aspectos tecnológicos, sensorial e nutricional. Lavras-MG, UFLA, 2013. 